\title{
Effects of Transgenic Soybean and Organic Soybean on Rat Penis Morphology during the Aging Process
}

\author{
Efectos de los Frijoles de Soja Transgénica y de Soja Orgánica en la \\ Morfología del Pene de Rata durante el Proceso de Envejecimiento
}

Corrêa, L. B. N. S. ${ }^{1}$; Contreiras E. C. ${ }^{1}$; Daleprane, J. B. ${ }^{2}$; Boaventura, G. T. ${ }^{2}$ : Figueiredo, M. A. ${ }^{3}$ \& Chagas, M. A. ${ }^{*}$

CORRÊA, L. B. N. S.; CONTREIRAS E.C.; DALEPRANE, J. B.; BOAVENTURA, G. T.; FIGUEIREDO, M.A. \& CHAGAS, M.A. Effects of transgenic soybean and organic soybean on rat penis morphology during the aging process. Int. J. Morphol., 35(3):1043$1049,2017$.

SUMMARY: The contents of soybean can modify the structure of the reproductive system, especially, when consumed for prolonged periods. In this study, we evaluated the effects of the consumption of transgenic soybean on rat penis morphology after prolonged use. Wistar rats $(n=30)$ were divided into three groups according to diet: Transgenic Soybean $(\mathrm{TS})$ group, Organic Soybean $(\mathrm{OS})$ group and Control (C) group. After 455 days of intake, the rats were sacrificed and the penises were excised and fixed in formalin for subsequent histological processing. The samples were stained with hematoxylin and eosin, Weigert's resorcin-fuchsin stain, and picrosirius red with polarization. The images were scanned for the histomorphometric analyses of the corpora cavernosa, corpus spongiosum, erectile tissue, and tunica albuginea as well as the measurement of the thickness of the tunica albuginea. The diameter and areas of the penile arteries with the intima and media tunica were also measured. The elastic fibers of the tunica albuginea, corpora cavernosa and corpus spongiosum were quantified using stereological methods. No significant differences were observed in the collagen and elastic components among the groups. We concluded that no statistically significant differences were found among the groups, demonstrating that the prolonged consumption of OS and TS does not affect the penile structure.

KEY WORDS: Phytoestrogens; Diet; Soybeans; Male; Morphology; Morphometry.

\section{INTRODUCTION}

Soy Glycine max (L.) Merr. is known worldwide for its health benefits. Consisting of phytoestrogens (genistein and daidzein), soy plays an important role in lowering the risk of cardiovascular diseases, reducing the risk of cancer, and the antioxidant effect (Ko, 2014; Reverri et al., 2015; Zhou et al., 2016; Zhang et al., 2016). Currently, it is considered a high-quality protein food and plays an important role for the benefits to health, especially when consumed regularly in the diet (Pelletier et al., 2002).

With the progress of modern biotechnology, genetically modified organisms (GMOs) or transgenic, including soybean, were developed and commercialized worldwide to meet growing demands (Natarajan et al., 2013). Transgenic soybean seeds are resistant to the herbicide glyphosate, because of the insertion of bacterial genes in the Agrobacterium variety Roundup Ready (RR), which results in decreased production cost and herbicide requirement during plant development (Rott et al., 2004).

However, new soybean varieties need to be assessed for quality and health safety (Natarajan et al.). Lappé et al. (1999), reported that the concentration of soy phytoestrogens is lower in transgenic than in organic soybean. The presence of the soy phytoestrogens, can lead structural and functional modifications in the reproductive tract during development and adulthood (Cardozo \& Baó, 2007; Cederroth et al., 2010). In concurrence with a report by Pan et al. (2008), consumption of large amounts of soy phytoestrogens can trigger erectile dysfunction, which involves erectile tissue. Huang et al. (2008) observed the morphological action of daidzein in 90-day-old rat penis. They reported an increase in the collagen content and a reduction in smooth muscles and elastic fibers in treated rats.

\footnotetext{
${ }^{1}$ Laboratory of Cellular and Extracellular Biomorphology, Federal Fluminense University (UFF), Brazil.

${ }^{2}$ Laboratory of Experimental Nutrition (LabNE), College of Nutrition, Federal Fluminense University (UFF), Brazil.

${ }^{3}$ Federal Rural do Rio de Janeiro University (UFRRJ), Brazil.
} 
CORRÊA, L. B. N. S.; CONTREIRAS E. C.; DALEPRANE, J. B.; BOAVENTURA, G. T.; FIGUEIREDO, M. A. \& CHAGAS, M. A. Effects of transgenic soybean and organic soybean on rat penis morphology during the aging process. Int. J. Morphol., 35(3):1043-1049, 2017.

No studies have correlated prolonged (15 months) moderate consumption of transgenic soybeans with possible morphological changes. We evaluated and compared the effects of prolonged administration of transgenic soybean with those of organic soybean on penile morphology in this study.

\section{MATERIAL AND METHOD}

Experimental Protocol. For this study, the experimental protocol was approved by the Ethics Committee for the Federal Fluminense University (UFF) (No. 57/02) and followed the rules of the National Research Council (US) ILAR. Thirty Wistar male rats from the Central Biotherium (NAL - UFF) were used. They were kept in cages with a constant temperature $\left(21-23^{\circ} \mathrm{C}\right)$, controlled light/dark cycle $(12 \mathrm{~h} / 12 \mathrm{~h})$, and food and water ad libitum.

After weaning (21 days), the 30 rats were divided into three groups of 10 animals each: the control group (CG) was fed with a $10 \%$ protein casein-based diet, the organic soybean (OS group) was fed with a $10 \%$ protein soy-based diet, and the transgenic soybean group (TS group) was fed with a $10 \%$ protein TS-based diet. The animals were fed the respective experimental diets for 15 months (455 days).

Diets. All diets were prepared at the Laboratory of Experimental Nutrition (LabNE), Department of Nutrition and Dietetics, UFF, Niteroi, RJ, Brazil. The TS and OS was supplied by Jasmine Integral Foods (PR, Brazil) and Bunge Foods (RS, Brazil), respectively. The other components of the diet were provided as follows: Maizena starch by Refinements of Maize Ltd. (PE, Brazil), refined sugar by União (RJ, Brazil), Liza soil oil by Cargill Agricultural Ltd. (SP, Brazil), Microcel cellulose by Blanver Ltd. (SP, Brazil). Casein, choline bitartrate, Cysteine, mixtures of minerals and vitamins were provided by Rhoster Commerce and Industry Ltd. (SP, Brazil). To prepare flour, soybean used was treated as defined by Soares et al. (2005).

The diets contained $10 \%$ protein ( $1.75 \%$ nitrogen) and $363.95 \mathrm{kcal}$ per $100 \mathrm{~g}$ added to the mixtures of vitamins and minerals according to the rules of the Committee on Laboratory Animal Diets (1979), modified according to the recommendations of the American Institute of Nutrition-93 (Reeves et al., 1993). The diet ingredients (Table I) were homogenized in an industrial mixer with boiling water. The resulting mass was transformed into tablets, which were dried in a ventilated oven at $60^{\circ} \mathrm{C}$ for $24 \mathrm{~h}$, properly identified and stored under refrigeration until use.
Histological Analyses. At the end of 455 days, the animals were sacrificed and the penises were excised. The penises were cleaved and fixed in $10 \%$ buffered formalin. Thereafter, they were processed using the routine paraffin embedded technique to obtain $5 \mu \mathrm{m}$-thick sections. The samples were stained with $\mathrm{HE}$ to evaluate the integrity of the specimens and perform histomorphometric analyses; Weigert's resorcin-fuchsin stain was used for stereological analysis; and Picrosirius red with polarizing microscopy was used for the standard observation of collagen fibers (Bancroft \& Cook, 1994). Histological processing and analyses were performed in the Laboratory of Cellular and Extracellular Biomorphology (Instituto Biomédico, UFF, Brazil).

\section{Histomorphometric Analyses of Corpora Cavernosa} and Corpus Spongiosum. The thickness and area of the corpora cavernosa and corpus spongiosum structures were measured. Histomorphometric images stained with HE (magnification $4 \mathrm{X}$ and $10 \mathrm{X}$ ) were scanned using the optical microscope Olympus BX-51 attached to an Olympus digital camera DP-72. The images were transferred to a monitor LG Flatron 1752t.

The scanned images were analyzed through ImageJ v1.50a software for the measurement of the total areas of the corpora cavernosa, corpus spongiosum, erectile tissue, and tunica albuginea of the corpora cavernosa; and the thickness of the corpora cavernosa and corpus spongiosum, as depicted in Figure 1.

Percentage of corpora cavernosa. The area of the trabeculae and sinuses of the erectile area were measured using the tools "Freehand" and "Threshold" of the Image J - FIJI v.1.50a program (National Institutes of Health, USA).

Assessment of elastic fibers and collagen. Sections were stained with Weigert's resorcin-fuchsin stain, with prior oxidation by oxone, examined by light microscopy (Olympus BX-51, final magnification of 400x). The images were transferred to a monitor LG Flatron 1752t to assess the elastic fiber system.

The fields were quantified by M42 test system after random selection. By points counting in planimetry method after superimposition of M42 grid on the display (Babinski et al., 2005). The data were tabulated and expressed as volumetric density ( $\mathrm{Vv}-\%)$.

The volume density ( $\mathrm{Vv}$ ) of the histological components were calculated as $\mathrm{Vv}=\mathrm{Pp} / \mathrm{Pt}$, where $\mathrm{p}$ is the tissue component under consideration (elastic fibers), $\mathrm{Pp}$ is the number of test points associated with $\mathrm{p}$, and $\mathrm{Pt}$ is the total number points of the M42 grid. 
Table I. Composition of the diets used for the assay $(\mathrm{g} / 100 \mathrm{~g})$

\begin{tabular}{lccc}
\hline \multicolumn{1}{c}{ Food $(\mathrm{g} / 100 \mathrm{~g})$} & $\mathrm{CG}^{1}$ & $\mathrm{OS}$ & $\mathrm{TS}^{3}$ \\
\hline Protein & 11.54 & 20.96 & 20.28 \\
Starch $^{4}$ & 61.41 & 57.23 & 58.04 \\
Refined sugar $^{5}$ & 10.00 & 10.00 & 10.00 \\
Mineral mix $^{6}$ & 3.50 & 3.50 & 3.50 \\
Vitamin mix $^{7}$ & 1.00 & 1.00 & 1.00 \\
Soy oil $^{8}$ & 7.00 & 2.81 & 2.94 \\
Cellulose $^{9}$ & 5.00 & 3.95 & 3.99 \\
Choline bitartrate $^{10}$ & 0.25 & 0.25 & 0.25 \\
Cysteine $^{10}$ & 0.30 & 0.30 & 0.00 \\
Total & 100.00 & 100.00 & 100.00 \\
\hline
\end{tabular}

The collagen fibers were observed by staining them using the picrosirius red stain associated with polarizing microscopy at 40x magnification. These elements were distinguished on the basis of their specific diameter (thick fibers with birefringence red-orange and thin fibers with green birefringence) (Junqueira \& Carneiro, 2008).

Arterial histomorphometry. We evaluated the overall diameter, total area, luminal area, and thickness of the penile artery using the program Image J. The arterial thickness of the intima and media were obtained from images stained with hematoxylin and eosin at 200x magnification.

Statistical analysis. For statistical analysis, the means obtained of each group were tabulated and submitted to the tests in GraphPad InStat 3.01 and presented as mean \pm standard deviation. The data obtained from histomorphometry and stereology were analyzed through statistical tests of Tukey and Kruskal-Wallis (ANOVA nonparametric). Statistical significance was defined as $\mathrm{p} \leq 0.05$.

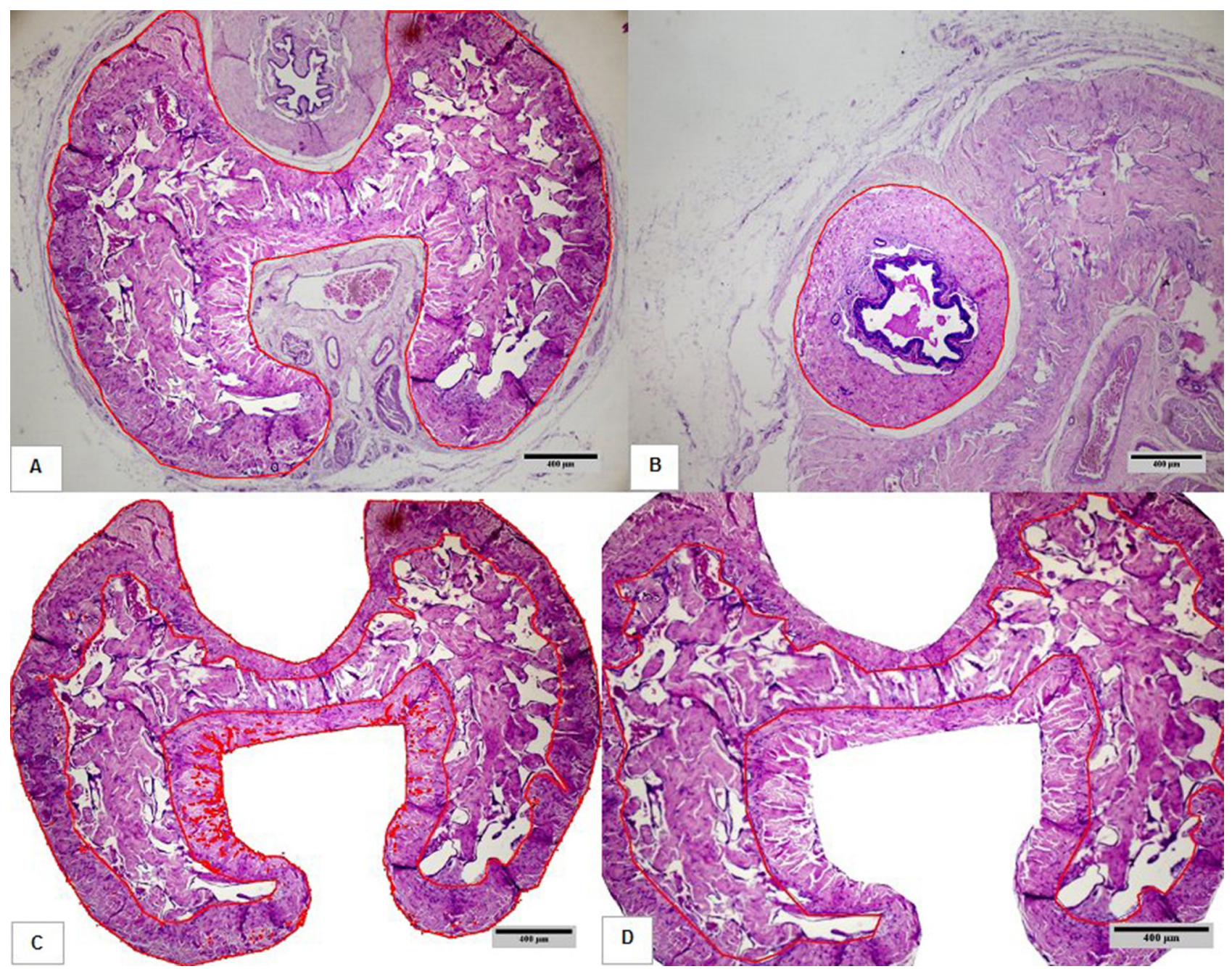

Fig. 1. Illustrative photomicrograph of histomorphometric analysis (marked in red) using the tools of the Fiji program (Image J) in penile body. A - Total area of the corpus cavernosum; B - Total area of corpus spongiosum; C - Area of tunica albuginea; D - Area of erectile tissue. Photo: HE stained, original magnification X 40. 


\section{RESULTS}

Histomorphometry of corpora cavernosa and corpus spongiosum. In Table II, the thickness tunica albuginea of corpora cavernosa showed higher OS and TS group. However, the thickness tunica albuginea of the corpus spongiosum values in the OS group was lower than those in the C group and TS group. The data showed no significant differences among the compared groups.

Regarding the area, the group fed OS and TS had lower averages than the $\mathrm{C}$ group. The tunica albuginea area of the corpora cavernosa had an approximate mean of the OS and TS. The total area of the corpora cavernosa and corpus spongiosum, the TS group had higher averages than did the OS group. The erectile tissue area, the OS and TS groups had lower averages than did the $\mathrm{C}$ group. However, the differences found in areas were not statistically significant.

The composition of the analyzed erectile area (Fig. 2) showed that OS group had higher, although not significantly higher, mean cavernous sinus area than did the other groups (Table III), and a percentage of $32.95 \%$, as observed in Table IV.
Elastic fibers. The stereological analysis showed that the volumetric density $(\mathrm{Vv})$ of the elastic system fibers in the corpora cavernosa were higher in the rats of the OS group than in rats of the other groups. In the corpus spongiosum, the $\mathrm{Vv}$ of elastic fibers was higher in the rats of the TS group than in rats from other groups. There was no significant difference among the groups, as shown in Table V.

Collagen fibers: Polarization microscopy. No changes were observed in the arrangement of collagen fibers in the three groups (Fig. 3). The typical orange birefringence of thick collagen fibers predominated in the analyzed samples.

Histomorphometry Analysis of the Penile Arteries. On the basis of measurement of penile vasculature, we analyzed the arterial diameter and thickness of the intima and media were analyzed. The OS and TS groups showed lower tubular diameter and thickness of the intima and media than the $\mathrm{C}$ group did. With regard to the area, the soybean groups (OS and TS) had lower means than the $\mathrm{C}$ group did. No significant differences were observed, as noted in Table VI.
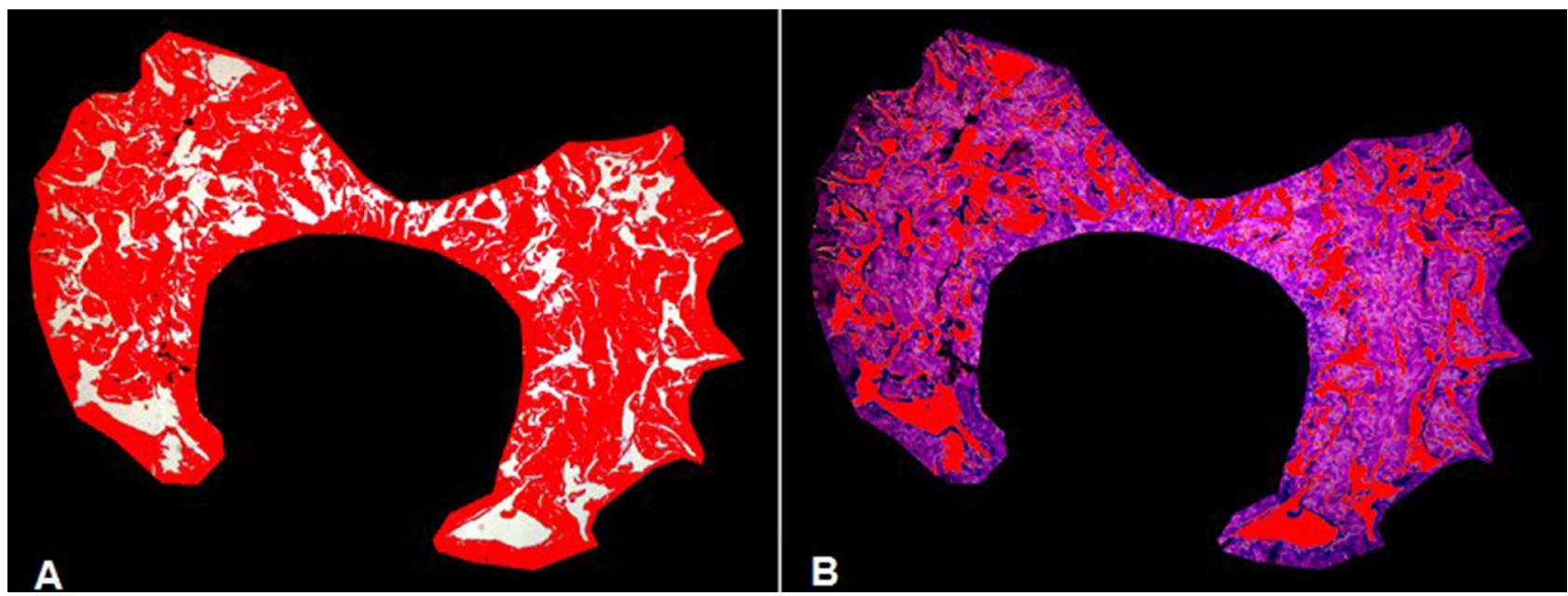

Fig. 2. Photomicrograph depicting the analysis of erectile tissue using the Image J program tools to determine the trabeculae area and cavernous sinus, marked in red. A - Area of trabeculae cavernosum; B - Area of sinus cavernous. TS, magnification 40x.

Table II. Thickness and areas of corpus cavernosum and corpus spongiosum structures of the rat penis.

\begin{tabular}{lcccc}
\hline Parameters & CG & OS & TS & $P$ value \\
\hline Thickness tunica albuginea of Corpus Cavernosum $(\mu \mathrm{m})$ & $200.22 \pm 56.60$ & $215.63 \pm 16.06$ & $213.52 \pm 17.65$ & 0.70 \\
Thickness tunica albuginea of Corpus Spongiosum $(\mu \mathrm{m})$ & $222.45 \pm 28.86$ & $210.57 \pm 35.98$ & $224.74 \pm 26.23$ & 0.68 \\
Area tunica albuginea of Corpus cavernosum $\left(\mathrm{mm}^{2}\right)$ & $2611.84 \pm 256.56$ & $2304.23 \pm 117,60$ & $2432.01 \pm 293.28$ & 0.11 \\
Total area of the Corpus cavernosum $\left(\mathrm{mm}^{2}\right)$ & $5543.32 \pm 575.69$ & $4971.22 \pm 214.68$ & $5248.51 \pm 245.33$ & 0.06 \\
Total area of the corpus spongiosum $\left(\mathrm{mm}^{2}\right)$ & $1060.73 \pm 122.06$ & $940.64 \pm 61.76$ & $990.32 \pm 123.51$ & 0.17 \\
Area Tissue Erectile $\left(\mathrm{mm}^{2}\right)$ & $2880.83 \pm 362.94$ & $2673.89 \pm 320.47$ & $2656.61 \pm 50601$ & 0.57
\end{tabular}

$* \mathrm{p}<0,05$ significant. CG: Control group; OS: Organic soybean group; TS: Transgenic soybean group. 
OS
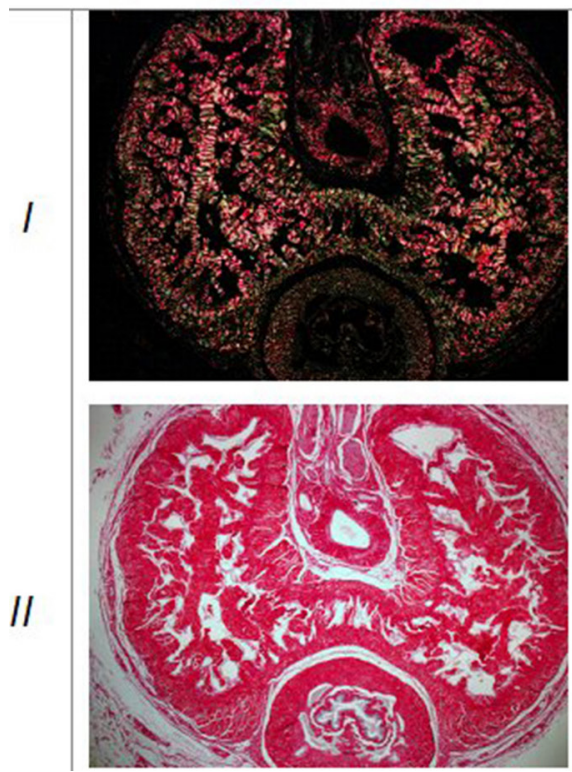

TS
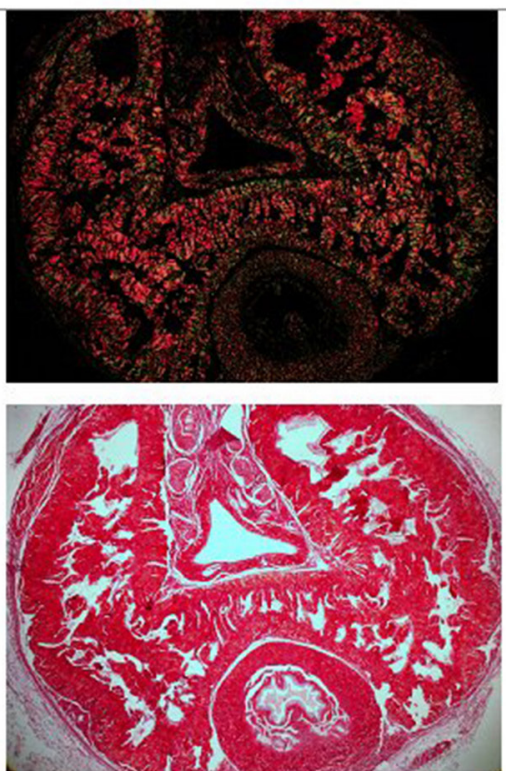

C
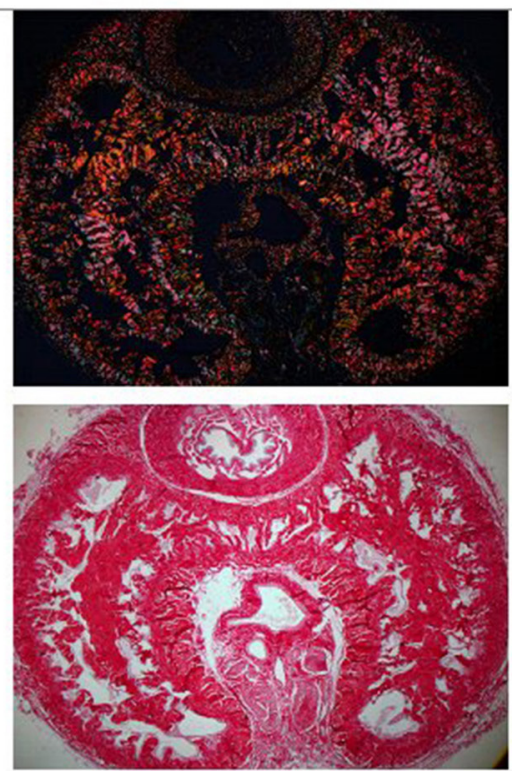

Fig. 3. Photomicrographs of collagen fibers in the corpus cavernosum and corpus spongiosum of the penises of rats from the different groups tested. The arrangement of fibers is seen in the first row. OS: Organic Soybean group; TS: Transgenic Soybean group; C: Control group Red Picrosirius with (I) and without (II) polarization Picrosirius Red, original magnification 40x.

Table III. Mean and standard deviation of the erectile tissue area.

\begin{tabular}{lcccc}
\hline \multicolumn{1}{c}{ Area $\left(\mathrm{mm}^{2}\right)$} & CG & OS & TS & $P$ value \\
\hline Trabeculae cavernosum & $2086.44 \pm 402.3$ & $1792.85 \pm 435.57$ & $1867.89 \pm 400.27$ & 0.46 \\
Sinus cavernosum & $714.52 \pm 192.19$ & $881.04 \pm 527.13$ & $788.71 \pm 166.55$ & 0.69 \\
\hline
\end{tabular}

*P $<0,05$ significant. CG: Control group; OS: Organic soybean group; TS: Transgenic soybean group.

Table IV. Distribution of Erectile Tissue structures in experiments groups.

\begin{tabular}{lccc}
\hline Porcentage & CG & OS & TS \\
\hline Trabeculae cavernosum & $74.49 \%$ & $67.05 \%$ & $70.31 \%$ \\
Sinus cavernosum & $25.51 \%$ & $32.95 \%$ & $29.69 \%$ \\
\hline
\end{tabular}

CG: Control group; OS: Organic soybean group; TS: Transgenic soybean group.

Table V. Elastic fibers found the tunica albuginea of the corpus cavernosum and corpus spongiosum of the penises of rats.

\begin{tabular}{lcccc}
\hline Media $(\%)$ & CG & OS & TS & P value \\
\hline Corpus cavernosum & $6.68 \pm 0.72$ & $8.84 \pm 2.31$ & $6.70 \pm 0.60$ & 0.27 \\
Corpus spongiosum & $19.85 \pm 2.67$ & $19.99 \pm 1.39$ & $21.78 \pm 2.19$ & 0.08 \\
\hline
\end{tabular}

$* \mathrm{P}<0,05$ significant. CG: Control group; OS: Organic soybean group; TS: Transgenic soybean group.

Table VI. Measurement of diameter and artery area of the rat penis.

\begin{tabular}{lcccc}
\hline Parameters & CG & OS & TS & $P$ value \\
\hline Total Diameter $(\mu \mathrm{m})$ & $157.05 \pm 19.32$ & $122.17 \pm 31.47$ & $127.50 \pm 28.42$ & 0.12 \\
Luminal Diameter $(\mu \mathrm{m})$ & $109.36 \pm 13.28$ & $91.11 \pm 26.50$ & $90.36 \pm 10.30$ & 0.21 \\
Thickness Intima/Media $(\mu \mathrm{m})$ & $24.67 \pm 5.98$ & $15.39 \pm 3.84$ & $18.84 \pm 8.16$ & 0.10 \\
Total Area Arterial $\left(\mathrm{mm}^{2}\right)$ & $18.18 \pm 5.25$ & $11.11 \pm 6.32$ & $11.66 \pm 7.34$ & 0.19 \\
Luminal Area Arterial $\left(\mathrm{mm}^{2}\right)$ & $6.58 \pm 3.23$ & $5.55 \pm 3.94$ & $4.41 \pm 2.85$ & 0.68 \\
\hline
\end{tabular}

$* \mathrm{P}<0.05$ significant CG: Control group; OS: Organic soybean group; TS: Transgenic soybean group. 


\section{DISCUSSION}

Because of its beneficial health effects, soy is commonly consumed. Soy seeds are rich in phytoestrogens, which are associated with prostate cancer prevention (Zhang et al.); this has led to increased soy consumption. Although phytoestrogens have weak estrogen-binding capacity compared with estradiol, their dietary consumption at sufficiently high levels for a long period can induce biological effects in humans and animals (Jefferson \& Newbold, 2000). In the male reproductive tract, estrogen receptors are present in the penis. In the presence of phytoestrogens, structural changes affecting erectile activity may occur (Srilatha \& Adaikan, 2004; Mowa, 2006).

In this study, we investigated the effects of prolonged consumption of organic and transgenic soybean on penile structure. No significant changes were observed in the area and thickness of the tunica albuginea, corpora cavernosa and corpus spongiosum in our histomorphometric analyses. Morphological changes of the penile structure indicate cases of erectile dysfunction. According to Huang et al. the intake of the purified phytoestrogen (daidzein) for 90 days at high concentrations leads to increased content of collagen and decreased content of smooth muscle and elastic fibers. In this study, a soy-based (OS and TS) balanced diet was given to Wistar rats for 455 days, and no alterations were observed in penile the structure.

Intracavernous structures are essential for penile erection, especially, elastic and collagen fibers. The amount and organization of elastic system fibers have fundamental importance in penile erection in experimental models (Maia et al., 2006). In our study, the elastic fibers of the corpora cavernosa and corpus spongiosum of the rats from the TS group did not exhibit significant differences in the volume density, compared with those of the rats from other groups, thereby indicating unaltered organ elasticity.

The organization of the different types of collagen fibers was also normal. The changes in the pattern of cavernous collagen fibers can cause decreased erectile tissue relaxation and normal fill the vascular space. Including soy in the diet did not alter the structure of the penis even though it was administered for a long period, despite the interference of aging. In our results, the arrangement of the erectile tissue was normal in the group fed TS. The integrity of the erectile structure suggests that prolonged and moderate consumption of transgenic soy has no effect on aging, which means that transgenic soy does not interfere with the critical periods of the development phase.
Oxidative stress is a major mechanism contributing to aging, which promotes cardiovascular disorders, especially, by disrupting the structure and function of the arteries (Costa \& Vendeira, 2008). Isoflavones have antioxidant properties and are capable of inhibiting the oxidation of lipoproteins. Therefore, isoflavones reduce the risk of cardiovascular diseases. The vascular structure of the groups tested in this study was preserved because of OS and TS consumption, despite aging. We investigated whether the thickness of the intima and media wall of the penile artery decreased. However, no significant change was detected, thereby demonstrating endothelial preservation of the vessel. Similarly, Daleprane et al. (2010), in a previous study, observed a decrease in the thickness of the vascular aorta wall using histomorphometry in rats fed with both types of soybeans. The decrease in thickness of the vascular aorta was attributed to decreased aortic remodeling in aged rats.

TS (RR glyphosate resistant) does not interfere with isoflavones and anti-nutritional factors. The secondary metabolites of TS and OS are not different (Zhou et al., 2011). However, Lappé et al. reported lower levels of phytoestrogens in TS than in OS. The presence of isoflavones is likely to cause reproductive disturbances on long-term administration. Pan et al., evaluated the effects of purified forms of daidzein and suggested that daily exposure of young male rats to phytoestrogens may result in the impairment of penile erection during adulthood. In a study similar to the present one, Cardozo et al. (2012), observed that the prolonged consumption of flaxseed meal does not alter penile development. Exposure to purified forms of phytoestrogens does not mimic the metabolic interaction that occurs in the body.

\section{CONCLUSION}

Our study demonstrates that the groups fed with OS and TS in moderate amounts do not exhibit changes in the structures of the corpora cavernosa and corpus spongiosum. Thus, the prolonged use of natural soy, when moderately administered, does not cause deleterious effects on the penile structure of the rats, even with advanced age.

CORRÊA, L. B. N. S.; CONTREIRAS, E. C.; DALEPRANE, J. B.; BOAVENTURA, G. T.; FIGUEIREDO, M. A. \& CHAGAS, M. A. Efectos de los frijoles de soja transgénica y de soja orgánica en la morfología del pene de rata durante el proceso de envejecimiento. Int. J. Morphol., 35(3):1135-1141, 2017.

RESUMEN: El contenido de frijoles de soja puede modificar la estructura del sistema reproductivo, especialmente, 
cuando se consume durante períodos prolongados. En este estudio, se evaluaron los efectos del consumo de frijoles de soja transgénica en la morfología del pene de rata después de un uso prolongado. Las ratas Wistar $(\mathrm{n}=30)$ se dividieron en tres grupos según la dieta: grupo de frijoles de soja transgénica (TS), grupo de frijoles de soja orgánica (OS) y grupo control (C). Después de 455 días de ingesta, se sacrificaron las ratas y se extirparon los penes y se fijaron en formalina para posterior procesamiento histológico. Las muestras se tiñeron con hematoxilina y eosina, tinción de resorcina-fucsina de Weigert y rojo de picrosirius con polarización. Las imágenes fueron escaneadas para análisis histomorfométrico de los cuerpos cavernosos, cuerpo esponjoso, tejido eréctil y túnica albugínea, así como para la medición del espesor de la túnica albugínea. También se midieron el diámetro y las áreas de las arterias penianas con las túnicas íntima y media. Se cuantificaron las fibras elásticas de la túnica albugínea, cuerpos cavernosos y cuerpos esponjosos utilizando métodos estereológicos. No se observaron diferencias significativas en los componentes colágenos y elásticos entre los grupos. Se concluyó que no se encontraron diferencias estadísticamente significativas entre los grupos, lo que demuestra que el consumo prolongado de OS y TS no afecta a la estructura del pene.

PALABRAS CLAVE: Fitoestrógenos; Dieta; Frijoles de soja; Macho; Morfología; Morfometría.

\section{REFERENCES}

Babinski, M. A.; de Brito Gitirana, L. B.; Chagas, M. A.; Abidú-Figueiredo, M. ; Costa, W. S. \& Sampaio, F. J. Immunohistochemical analysis of smooth muscle cells and volumetric density of the elastic system fibers of wild boar (Sus scrofa) penis. Anim. Reprod. Sci., 86(3-4):317-28, 2005.

Bancroft, J. D. \& Cook, H. C. Manual of Histological Techniques and their Diagnostic Application. Edinburgh, Churchill Livingstone, 1994. pp.35-67.

Cardozo, J. R. \& Báo, S. N. Effects of chronic exposure to soy meal containing diet or soy derived isoflavones supplement on semen production and reproductive systemEffects of chronic exposure to soy meal containing diet or soy derived isoflavones supplement on semen production and reproductive system of male rabbits. Anim. Reprod. Sci., 97(3-4):237-45, 2007.

Cardozo, L. F. M. F.; Boaventura, G. T.; Brant, L. H.; Pereira, V. A.; Velarde, L. G. C. \& Chagas, M.A. Prolonged consumption of flaxseed flour increases the 17b-estradiol hormone without causing adverse effects on the histomorphology of Wistar rats' penis. Food Chem. Toxicol., 50(11):4092-6, 2012.

Cederroth, C. R.; Zimmermann, C.; Beny, J. L.; Schaad, O.; Combepine, C.; Descombes, P.; Doerge, D. R.; Pralong, F. P.; Vassalli, J. D. \& Nef, S. Potential detrimental effects of a phytoestrogen-rich diet on male fertility in mice. Mol. Cell. Endocrinol., 321(2):152-60, 2010.

Costa, C. \& Vendeira, P. Does erectile tissue angioarchitecture modify with aging? An immunohistological and morphometric approach. J. Sex. Med., 5(4):833-40, 2008.

Daleprane, J. B.; Chagas, M. A.; Vellarde, G. C.; Ramos, C. F. \& Boaventura, G.T.The impact of non- and genetically modified soybean diets in aorta wall remodeling. J. Food Sci., 75(7):126-31, 2010.

Huang, Y.; Pan, L.; Xia, X.; Feng, Y.; Jiang, C. \& Cui, Y. Long-term effects of phytoestrogen daidzein on penile cavernosal structures in adult rats. Urology, 72(1):220-4, 2008.

Jefferson, W. N. \& Newbold, R. R. Potential endocrine-modulating effects of various phytoestrogens in the diet. Nutrition, 16(7-8):658-62, 2000.
Junqueira, L. C. U. \& Carneiro, J. Histologia Básica. Rio de Janeiro, Guanabara Koogan, 2008.

Ko, K. P. Isoflavones: chemistry, analysis, functions and effects on health and cancer. Asian Pac. J. Cancer Prev., 15(17):7001-10, 2014.

Lappé, M. A.; Bailey, E. B.; Childress, C. \& Setchell, K. D. R. Alterations in clinically important phytoestrogens in genetically modified, herbicide-tolerant soybeans. J. Med. Food, 1(4):241-5, 1998.

Maia, R. S.; Babinski, M. A.; Figueiredo, M. A.; Chagas, M. A.; Costa, W. S. \& Sampaio, F. J. Concentration of elastic system fibers in the corpus cavernosum, corpus spongiosum, and tunica albuginea in the rabbit penis. Int. J. Impot. Res., 18(2):121-5, 2006.

Mowa, C. N.; Jesmin, S. \& Miyauchi,T. The penis: a new target and source of estrogen in male reproduction. Histol. Histopathol., 21(1):53-67, 2006.

Natarajan, S.; Luthria, D.; Bae, H.; Lakshman, D. \& Mitra, A. Transgenic soybeans and soybean protein analysis: an overview. J. Agric. Food Chem., 61(48):11736-43, 2013.

Pan, L.; Xia, X.; Feng, Y.; Jiang, C.; Cui, Y. \& Huang, Y. Exposure of juvenile rats to the phytoestrogen daidzein impairs erectile function in a dose-related manner in adulthood. J. Androl., 29(1):55-62, 2008.

Pelletier, S.; Kundrat, S. \& Hasler, C. M. Effects of an educational program on intent to consume functional foods. J.Am. Diet.Assoc., 102(9):1297$300,2002$.

Reeves, P. G.; Nielsen, F. H. \& Fahey, G. C. Jr. AIN-93 purified diets for laboratory rodents: final report of the American Institute of Nutrition ad hoc writing committee on the reformulation of the AIN-76A rodent diet. J. Nutr., 123(11):1939-51, 1993.

Reverri, E. J.; LaSalle, C. D.; Franke, A. A. \& Steinberg, F. M. Soy provides modest benefits on endothelial function without affecting inflammatory biomarkers in adults at cardiometabolic risk. Mol. Nutr. Food Res., 59(2):323-33, 2015

Rott, M.E.; Lawrence, T. S.; Wall, E. M. \& Green, M. J. Detection and quantification of roundup ready soy in foods by conventional and real-time polymerase chain reaction. J. Agric. Food Chem., 52(16):5223-32, 2004.

Soares, L. L.; Lucas, A. M. \& Boaventura, G. T. Can organic and transgenic soy be used as a substitute for animal protein by rats? Braz. J. Med Biol. Res., 38(4):583-6, 2005.

Srilatha, B. \& Adaikan, P. G. Estrogen and phytoestrogen predispose to erectile dysfunction: do ER-alpha and ER-beta in the cavernosum play a role? Urology, 63(2):382-6, 2004.

Zhang, H. Y.; Cui, J.; Zhang, Y.; Wang, Z. L.; Chong, T. \& Wang, Z. M. Isoflavones and prostate cancer: A review of some critical issues. Chin. Med.J. (Engl.), 129(3):341-7, 2016.

Zhou, J.; Berman, K. H.; Breeze, M. L.; Nemeth, M. A.; Oliveira, W. S.; Braga, D. P.; Berger, G. U. \& Harrigan, G. G. Compositional variability in conventional and glyphosate-tolerant soybean (Glycine max L.) varieties grown in different regions in Brazil. J. Agric. Food Chem., 59(21):11652-6, 2011.

Zhou, Y.; Li, Y.; Zhou, T.; Zheng, J.; Li, S. \& Li, H. B. Dietary natural products for prevention and treatment of liver cancer. Nutrients, $8(3): 156,2016$

Corresponding Author:

Maurício A. Chagas

Fluminense Federal University - UFF

Laboratory Cellular and Extracelular Biomorphology

Rua Hernani Mello, 101- São Domingos

Niterói, RJ, CEP 24.210-130

BRAZIL

Received: 22-02-2017

Accepted: 10-04-2017

E-mail: chagas.m@gmail.com 